\title{
Znaczenie wspólnych badań historycznych i paleoekologicznych nad wpływem człowieka na środowisko. Przykład ze stanowiska Kazanie we wschodniej Wielkopolsce ${ }^{*}$
}

\section{Sambor Czerwiński}

https://orcid.org/0000-0003-3422-040X

Laboratorium Ekologii i Monitoringu Mokradeł, Wydział Nauk Geograficznych i Geologicznych, Uniwersytet im. Adama Mickiewicza; Zakład Biogeografii i Paleoekologii, Wydział Nauk Geograficznych i Geologicznych, Uniwersytet im. Adama Mickiewicza

\section{Piotr Guzowski}

https://orcid.org/0000-0002-6494-4217

Instytut Historii i Nauk Politycznych, Uniwersytet w Białymstoku

\section{Monika Karpińska-Kołaczek}

https://orcid.org/0000-0002-3249-7408

Laboratorium Ekologii i Monitoringu Mokradeł, Wydział Nauk Geograficznych i Geologicznych, Uniwersytet im. Adama Mickiewicza; Zakład Biogeografii i Paleoekologii, Wydział Nauk Geograficznych i Geologicznych, Uniwersytet im. Adama Mickiewicza; Instytut Historii i Nauk Politycznych, Uniwersytet w Białymstoku

\section{Mariusz Lamentowicz}

https://orcid.org/0000-0003-0429-15301

Laboratorium Ekologii i Monitoringu Mokradeł, Wydział Nauk Geograficznych i Geologicznych, Uniwersytet im. Adama Mickiewicza; Zakład Biogeografii i Paleoekologii, Wydział Nauk Geograficznych i Geologicznych, Uniwersytet im. Adama Mickiewicza

\section{Mariusz Gałka}

https://orcid.org/0000-0001-8906-944X

Katedra Geobotaniki i Ekologii Roślin, Wydział Biologii i Ochrony Środowiska, Uniwersytet Łódzki

\section{Piotr Kołaczek}

https://orcid.org/0000-0003-2552-8269

Zakład Biogeografii i Paleoekologii, Wydział Nauk Geograficznych i Geologicznych, Uniwersytet im. Adama Mickiewicza

\section{Adam Izdebski}

https://orcid.org/0000-0002-3456-54784

Max Planck Institute for the Science of Human History; Instytut Historii, Uniwersytet Jagielloński

\section{Radosław Poniat}

https://orcid.org/0000-0001-7384-3920

Instytut Historii i Nauk Politycznych, Uniwersytet w Białymstoku

* Publikacja finansowana ze środków Narodowego Programu Rozwoju Humanistyki za lata 2016-2019. 
Zarys treści: Celem artykułu jest przedstawienie potencjału interdyscyplinarnych badań nad wpływem człowieka na środowisko w przeszłości na przykładzie Wielkopolski. Zostaną w nim wykorzystane wysokorozdzielcze analizy paleoekologiczne źródeł przyrodniczych wydobytych z torfowiska Kazanie oraz materiały archeologiczne i historyczne obrazujące osadnictwo i aktywność gospodarczą mieszkańców Pobiedzisk i okolicznych wsi w ciągu ostatnich 1200 lat.

Stowa kluczowe: analiza paleoekologiczna, torfowisko, historyczny wpływ człowieka, pyłek, historyczne zmiany środowiska, przełomy gospodarcze

\section{Wstęp \\ W ostatnich latach możemy zaobserwować coraz większą liczbę interdyscyplinarnych badań łączących podejście paleoekolo- giczne i historyczne ${ }^{1}$. Wspólna praca nie jest jednak standardem - w badaniach}

\footnotetext{
${ }^{1}$ S. Veski, K. Koppel, A. Poska, Integrated palaeoecological and historical data in the service of fine-resolution land use and ecological change assessment during the last 1000 years in Röuge, southern Estonia. Land use and ecological change assessment in southern Estonia, ,Journal of Biogeography", 32 (8), 2005, s. 1473-1488; M.C. Bal i in., Fire history and human activities during the last 3300 calyr BP in Spain's Central Pyrenees. The case of the Estany de Burg, „Palaeogeography, Palaeoclimatology, Palaeoecology”, 300 (1-4), 2011, s. 179-190; Q.Y. Cui i in., Historical land-use and landscape change in southern Sweden and implications for present and future biodiversity, „Ecology and Evolution", 4 (18), 2014, s. 3555-3570; I. Mazzini i in., Holocene evolution of Lake Shkodra. Multidisciplinary evidence for diachronic landscape change in northern Albania, „Quaternary Science Reviews”, 136, 2016, s. 85-95; A. Wacnik i in., Determining the responses of vegetation to natural processes and human impacts in north-eastern Poland during the last millennium. Combined pollen, geochemical and historical data, „Vegetation History and Archaeobotany”, 25 (5), 2016, s. 479-498; P. Bitušík, Tracking human impact in a mining landscape using lake sediments. A multi-proxy palaeolimnological study, „Palaeogeography, Palaeoclimatology, Palaeoecology”, 504, 2018, s. 23-33; R.M. Fyfe, J. Woodbridge, C.N. Roberts, Trajectories of change in Mediterranean Holocene vegetation through classification of pollen data, „Vegetation History and Archaeobotany”, 27 (2), 2018, s. 351-364; G. Hörnberg i in., Anthropogenic use of fire led to degraded Scots pine-lichen forest in northern Sweden, „Anthropocene”, 24, 2018, s. 14-29; A. Poska i in., Reading past landscapes. Combining modern and historical records, maps, pollen-based vegetation reconstructions, and the socioeconomic background, „Landscape Ecology", 33 (4), 2018, s. 529-546; S. Riddell i in., Cereal cultivation as a correlate of high social status in medieval Iceland, „Vegetation History and Archaeobotany", 27 (5), 2018, s. 679-696; M. Trapote i in., High-resolution (sub-decadal) pollen analysis of varved sediments from Lake Montcortès (southern Pyrenean flank). A fine-tuned record of landscape dynamics and human impact during the last 500 years, „Review of Palaeobotany and Palynology”, 259, 2018, s. 207-222.
}

Abstract: The aim of the article is to present the potential of interdisciplinary research on the human impact on the environment in the past on the example of a site in Greater Poland (Wielkopolska). It uses high-resolution palaeoecological analyses of peat archives from the Kazanie peat bog as well as archaeological and historical materials reflecting the settlement and economic activity of the inhabitants of Pobiedziska and surrounding villages throughout last 1200 years.

Keywords: palaeoecological analysis, peat bog, historical influence of man, pollen, historical changes of environment, turning points in economic history

paleoekologicznych dotyczących wpływu człowieka na środowisko rzadko wykorzystuje się wiedzę historyków, a i historiografia nieczęsto korzysta $\mathrm{z}$ dorobku nauk przyrodniczych ${ }^{2}$. Tymczasem zestaw tradycyjnych źródeł historycznych, zwłaszcza związanych z dziejami gospodarczymi jak różnego rodzaju inwentarze dóbr, rejestry podatkowe, księgi rachunkowe czy nawet źródła sądowe, dostarczające podstawowych informacji o aktywności ekonomicznej człowieka, która w okresie preindustrialnym musiała być przecież ściśle związana z przyrodą - może zostać uzupełniony i rozszerzony o dane przyrodnicze ${ }^{3}$. W przypadku epok starszych (jak starożytność i średniowiecze), które były ubogie w masowe świadectwa pisane, jest

\footnotetext{
${ }^{2}$ Interdyscyplinarne spojrzenie na wzajemne relacje człowieka i przyrody widoczne jest w pracach Jana Tyszkiewicza: J. Tyszkiewicz, Środowisko naturalne i antroporegiony dorzecza Narwi przed 1000 lat, Wrocław 1975; tenże, Ludzie i przyroda w Polsce średniowiecznej, Warszawa 1983. Zwrócił on również uwagę na możliwości wykorzystania dorobku nauk przyrodniczych w badaniach humanistycznych: tenże, Człowiek średniowiecza w przyrodzie: jako jej element i moderator, w: Człowiek w średniowieczu. Między biologią a historią, red. A. Szymczakowa, Łódź 2009, s. 15-24; tenże, Geografia historyczna. Zarys problematyki, Warszawa 2013, s. 240-325.

${ }^{3} \mathrm{~A}$. Izdebski i in., On the use of palynological data in economic history. New methods and an application to agricultural output in Central Europe, 0-2000 AD, „Explorations in Economic History”, 59, 2016, s. 17-39; A. Izdebski i in., Realising consilience. How better communication between archaeologists, historians and natural scientists can transform the study of past climate change in the Mediterranean, "Quaternary Science Reviews", 136, 2016, s. 5-22; A. Izdebski, Średniowieczni Rzymianie i przyroda. Interdyscyplinarna historia środowiskowa, Kraków 2018.
} 
to wręcz konieczne. Połączenie warsztatów historycznego, archeologicznego i przyrodniczego otwiera przed nauką nową perspektywę wspólnych badań nad rolą i oddziaływaniem człowieka w środowisku w ciągu setek lub nawet tysięcy lat ${ }^{4}$. Próbę wykorzystania jej potencjału podjęto w projekcie „W poszukiwaniu transdyscyplinarnej synergii: przełomy gospodarcze Polski z perspektywy historyczno-przyrodniczej na tle europejskim", którego efektem jest prezentowany artykuł.

Historia badań paleoekologicznych nierozerwalnie wiąże się z analizą pyłkową Dzięki ziarnom pyłku roślin nagromadzonych w archiwach paleoekologicznych, jak torfy czy osady jeziorne, możliwa jest rekonstrukcja roślinności i zidentyfikowanie faz aktywności gospodarczej człowieka ${ }^{6}$. Informacje o przekształceniach środowiska zachowane w źródłach przyrodniczych możliwe są do odczytania m.in. dzięki udziałom procentowym antropogenicznych taksonów pyłku, np. bylicy (Artemisia), babki lancetowatej (Plantagolanceolata), komosowatych (Chenopodiaceae), albo pyłków związanych z działalnością rolniczą, np. zbóż (Cerealia) i chabra bławatka (Centaureacyanus) ${ }^{7}$. Wzrost antropogenicznych udziałów procentowych taksonów pyłku oznacza zatem większy wpływ człowieka na przekształcenia środowiska w otoczeniu danego stanowiska badań. Dla przykładu jednoczesny nagły

\footnotetext{
${ }^{4} \mathrm{~J}$. Haldon i in., History meets palaeoscience. Consilience and collaboration in studying past societal responses to environmental change, „Proceedings of the National Academy of Sciences of the United States of America", 115 (13), 2018, s. 3210-3218.

${ }^{5}$ Przystępnych informacji na temat analizy palinologicznej oraz technik obróbki osadów jeziornych i torfowych z punktu widzenia nauk historycznych dostarcza artykuł: A. Izdebski i in., Historia przyrodniczo-gospodarcza Polski w świetle analizy ilościowej danych palinologicznych, „Historyka. Studia Metodologiczne”, 45, 2015, s. 127-160.

${ }^{6}$ K.E. Behre, The interpretation of anthropogenic indicators in pollen diagrams, „Pollen et Spores”, 23, 1981, s. 225-245; B.E. Berglund, M. Ralska-Jasiewiczowa, Pollen analysis, w: Handbook of Holocene palaeoecology and palaeohydrology, ed. B.E. Berglund, Chichester-New York-Brisbane-Toronto-Singapore 1986, s. 455-484; M.J. Gaillard, Archaeological applications, w: History of Quaternary science, ed. S.E. Elias, Egham 2013, s. 880-903.

${ }^{7}$ Tamże.
}

spadek udziału procentowego taksonów pyłku drzew liściastych (buka, dębu czy grabu) i wzrost udziału procentowego taksonów pyłku zbóż może stanowić istotną informację o wylesieniu danego obszaru pod uprawy w danym okresie historycznym. W przypadku badań prezentowanych w niniejszym artykule informacje te pozyskiwane są z osadów torfowiska Kazanie, położonego $25 \mathrm{~km}$ na północny wschód od Poznania, niedaleko Pobiedzisk (diagram 1$)^{8}$. Wybór stanowiska podyktowany został jego wyjątkowym położeniem w sercu Wielkopolski i rodzącego się państwa, a jednocześnie możliwościami, jakie daje w zakresie analizy przyrodniczej, ponieważ torfowisko dokumentuje dwanaście ostatnich wieków bez przerw sedymentacyjnych, które mogłyby zakłócić bądź uniemożliwić interpretację paleoekologiczną. Niezbędnym etapem badań paleoekologicznych jest ustalenie wiarygodnej chronologii dla badanych osadów. Bazuje ona na koncentracjach radioaktywnych izotopów węgla czy ołowiu. Niestety, wysoka kosztochłonność technik datowania materiałów organicznych sprawia, że w wielu pracach naukowych chronologie oparte są o niedostateczną rozdzielczość datowań. Brak dokładnej chronologii i ciąłego próbkowania do analiz paleoekologicznych prowadzi do większej niepewności podczas interpretacji wyników badań9. Stąd też z jednej strony pewne przyrodnicze odzwierciedlenia wydarzeń historycznych mogą zostać pominięte, a przy niedokładnych chronologiach bezwzględnych - przesunięte w zapisie paleoekologicznym, co z kolei sprawia, że ich przydatność do porównań z danymi historycznymi jest mocno ograniczona. Odpowiedzią na wyzwania wynikające

\footnotetext{
${ }^{8}$ Szerzej o metodologii badań przyrodniczych zastosowanych w artykule zob. M. Lamentowicz i in., Znaczenie wysokorozdzielczych wielowskaźnikowych (multi-proxy) badań paleokologicznych dla geografii historycznej i historii gospodarczej w niniejszym tomie.

${ }^{9}$ P. Kołaczek i in., Increased radiocarbon dating resolution of ombrotrophic peat profiles reveals periods of disturbance which were previously undetected, „Quaternary Geochronology”, 52, 2019, s. 21-28.
} 


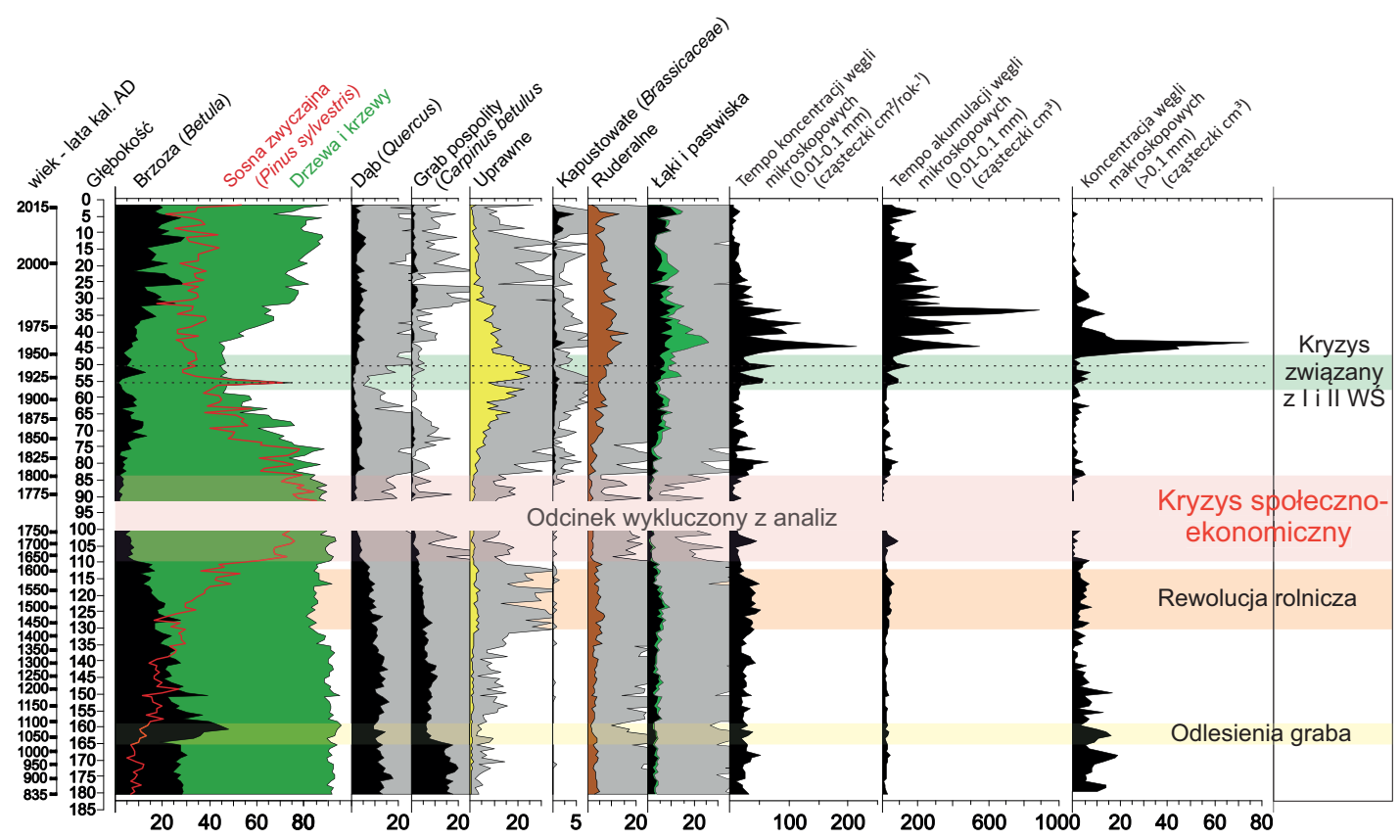

Diagram 1. Uproszczony diagram pyłkowy dla stanowiska Kazanie. Krzywe reprezentują wybrane taksony pyłku drzew i krzewów, a także zgrupowań (wskaźników) pyłku roślin charakterystycznych dla działalności człowieka. Przedstawiono je w skali procentowej, a szare tto oznacza ich dziesięciokrotne powiększenie (\%o). Zmiany głębokości w sekwencji pionowej osadów (po wcześniejszym ich datowaniu) pozwalają na odczytywanie struktury roślinności w czasie, a więc pośrednie wnioskowanie o działalności człowieka w ostatnich dwunastu stuleciach (w tym przypadku). Krzywa akumulacji i koncentracji węgli mikroskopijnych przedstawiona jest w tysiącach

z ograniczeń obu analiz (braku źródeł historycznych czy niedokładności chronologicznej) jest zatem wspólny wysiłek historyków i przyrodników. Ma on na celu wypracowanie nowego podejścia w równoległym badaniu źródeł historycznych i danych przyrodniczych, czego efektem są wyniki badań przedstawione w niniejszej pracy.

Analiza osadów pobranych z torfowiska Kazanie metodą paleoekologiczną - bazująca głównie na danych palinologicznych (pyłkowych) i mikrowęglowych, wsparta precyzyjnym datowaniem radiowęglowym ${ }^{14} \mathrm{C}$ za pomocą metody $\mathrm{AMS}^{10}$ - jest próbą określenia wpływu człowieka na środowisko w ostatnich dwunastu wiekach.

\footnotetext{
${ }^{10}$ AMS (accelerator mass spectrometry) - szybsza, bardziej nowoczesna i dokładniejsza metoda datowania oznaczająca spektrometrię mas z użyciem akceleratora. Bazuje na odróżnieniu izotopów węgla ${ }^{14} \mathrm{C}$ od ${ }^{13} \mathrm{C}{ }^{12} \mathrm{C}$.
}

Jej dopełnienie stanowi wnikliwa analiza źródeł typowych dla warsztatu historycznego. W przypadku wczesnego średniowiecza niezbędne jest wykorzystanie dokumentacji i opracowań archeologicznych oraz źródeł historiograficznych (np. kronik), a od okresu kolonizacji późnego średniowiecza - zazwyczaj także źródeł masowych, począwszy od przywilejów lokacyjnych, do rejestrów podatkowych czy inwentarzy dóbr. W analizie ostatnich stuleci niezwykle przydatne okazują się także źródła kartograficzne ${ }^{11}$.

W niniejszej pracy przedstawiona została lokalna historia zmian krajobrazu w okolicach stanowiska Kazanie. Zawiera ona opis ogólnych schematów wzajemnego oddziaływania między człowiekiem

\footnotetext{
${ }^{11}$ B. Szady, Dawna mapa jako źródło w badaniach geograficzno-historycznych w Polsce, „Kwartalnik Historii Kultury Materialnej”, 66 (2), 2018, s. 129-140.
} 
i środowiskiem; szczegółowa rekonstrukcja przyrodnicza przedstawiona zostanie natomiast w osobnej publikacji. Skupiono się tu zatem na najważniejszych wydarzeniach z punktu widzenia odpowiedzi środowiska na wydarzenia społeczno-ekonomiczne (możliwych do interpretacji głównie na podstawie danych pyłkowych). Nadrzędnym celem pracy jest przedstawienie komplementarności danych paleoekologicznych i historycznych oraz możliwości wykorzystania danych paleoekologicznych w historycznych studiach porównawczych. Ponadto celem artykułu jest wskazanie możliwości współpracy między badaczami przeszłości człowieka i przyrody oraz zaprezentowanie interdyscyplinarnego standardu badawczego w zakresie klasycznych pytań historycznych o przełomy gospodarcze.

\section{Początki państwa piastowskiego}

Wyniki analizy palinologicznej oraz datowań radiowęglowych wskazały, że w latach 835 (+/-40 lat) - $1025(+/-21)$ na badanym terenie dominowały lasy zbliżone do pierwotnych, a więc składające się z gatunków rodzimych, które odnawiają się w sposób naturalny i nie noszą wyraźnych śladów działalności człowieka, a zachodzące w nich procesy ekologiczne nie są zaburzone $^{12}$. Tereny otwarte stanowity zdecydowaną mniejszość, o czym świadczy wysoki udział pyłku drzew i krzewów w analizowanych próbkach. Przeważającym typem lasu w okolicy stanowiska (w północno-zachodniej części Równiny Wrzesińskiej) i Wysoczyzny Gnieźnieńskiej był w tym okresie grąd środkowoeuropejski, składający się głównie z drzew liściastych, jak grab pospolity (Carpinusbetulus) i dąb (Quercus).

Powstanie państwa wczesnopiastowskiego przyniosło budowę sieci grodów stanowiących podstawę jego organizacji polityczno-militarnej ${ }^{13}$. W Wielkopolsce,

\footnotetext{
${ }^{12}$ F.M. Sabatini i in., Where are Europe's last primary forests? , „Diversity and Distributions", 24 (12), 2018, s. 1890-1892.

${ }^{13}$ M. Kara, Najstarsze państwo Piastów - rezultat przełomu czy kontynuacji? Studium archeologiczne, Poznań 2009, s. 253-321; M. Kara,
}

w tym na badanym terenie, osiedla obronne zbudowano w X i XI w. Archeolodzy odkryli pozostałości grodów w takich miejscach jak Góra, Kociałkowa Górka, Moraczewo czy Pobiedziska. W ramach naszych badań przeanalizowana została dokumentacja badań powierzchniowych przeprowadzonych w ramach projektu Archeologiczne Zdjęcie Polski ${ }^{14}$. Choć spotyka się ona z surowymi ocenami samych archeologów ${ }^{15}$ (zwracają uwagę na błędy w ewidencji, gdzie m.in. rejestrowano ślady i punkty osadnicze na podstawie ceramiki znajdowanej na polach w pobliżu historycznych wsi, a jednocześnie zdarzały się pominięcia samych stref habitacji), to jednak umożliwia podstawową orientację w rozwoju wczesnośredniowiecznego osadnictwa. Dlatego podchodząc do zarejestrowanych zabytków agregatywnie (a więc bez szczegółowej weryfikacji prawidłowości przeprowadzonej na kartach ewidencyjnych klasyfikacji), trzeba przyjąć znaczny wzrost zarejestrowanych śladów, punktów i osad funkcjonujących od końca X stulecia (wykres 1).

Rozwój demograficzny musiał pociągnąć za sobą wzrost wykorzystania zasobów leśnych, a także wpływać na ich strukturę. Dzięki analizie palinologicznej możemy zaobserwować gwałtowny spadek udziału procentowego graba między rokiem 1025 (+/-21) a $1090(+/-26)$ - z 17,5 do 6 proc., co może świadczyć o celowym karczowaniu lasu przez lokalną społeczność. Jak podaje Katarzyna Cywa, we wczesnym średniowieczu chętnie używano graba w celach opałowych ${ }^{16}$. Niemniej jednak spadek udziału procentowego graba pospolitego tylko w niewielkim stopniu koresponduje

M. Makohonienko, Wielkopolska krainą grodów - krajobraz kulturowy kolebki państwa polskiego w świetle nowych ustaleń chronologicznych, „Landform Analysis”, 16, 2011, s. 20-25.

${ }^{14}$ Zdjęcie archeologiczne Polski, red. M. Konopka, Warszawa 1981.

${ }^{15}$ Archeologiczne Zdjęcie Polski - metoda i doświadczenia. Próba oceny, red. D. Jaskanis, Warszawa 1996.

${ }^{16} \mathrm{~K}$. Cywa, Trees and shrubs used in medieval Poland for making everyday objects, „Vegetation History and Archaeobotany”, 27 (1), 2018, s. 111-136. 

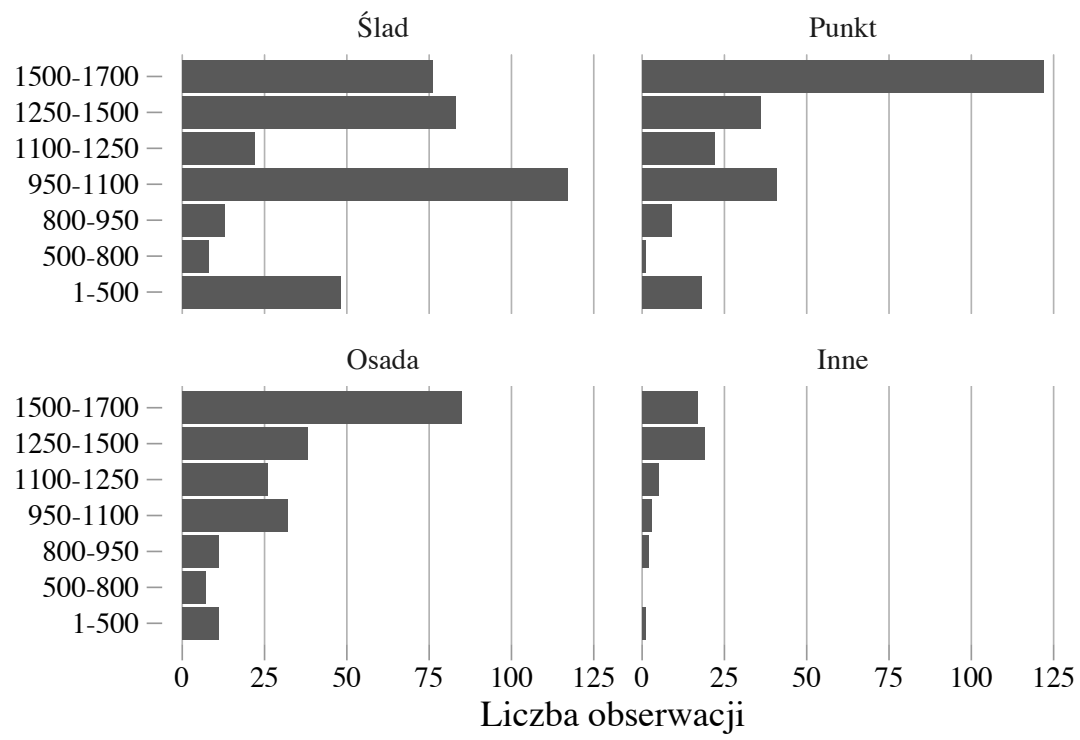

Wykres 1. Rejestracja osad, punktów iśladów z okolicy torfowiska Kazanie w materiałach Archeologicznego Zdjęcia Polski. Źródto: oprac. własne na podstawie AZP

ze wzrostem udziału węgli mikroskopowych (frakcja $>0,1 \mathrm{~mm}$ ) notowanym w tym okresie - z ok. 2 tys. fragmentów węgla na centymetr kwadratowy rocznie w $1045 \mathrm{r}$. (+/-25) do 4 tys. w 1090 (+/-26). W przeciwieństwie do graba udział dębu w lasach utrzymywał się w tym okresie na podobnym poziomie, mimo że jego drewno często stanowiło główny materiał do budowy grodów ${ }^{17}$. Można więc mówić o selektywnym karczowaniu lasu. Ze względu na obfite występowanie na Wysoczyźnie Gnieźnieńskiej i w okolicy stanowiska graba $^{18}$ to prawdopodobnie właśnie ten

\footnotetext{
${ }^{17}$ W. Dzieduszycki, Wykorzystanie surowca drzewnego we wczesnośredniowiecznej i średniowiecznej Kruszwicy, „Kwartalnik Historii Kultury Materialnej", 24 (1), 1976, s. 35-54.

${ }^{18}$ B. Jankowska, Szata roślinna okolic Gopła w późnym glacjale i holocenie oraz wpływ osadnictwa na jej rozwój w świetle badań paleobotanicznych, „Przegląd Archeologiczny”, 27, 1980, s. 5-41; A. Filbrandt, Badania palinologiczne osadów limnicznych jeziora Kamionek, w: Wstęp do paleoekologii Lednickiego Parku Krajobrazowego, red. K. Tobolski, Poznań 1991, s. 81-86; K. Tobolski, Dotychczasowy stan badań paleobotanicznych i biostratygraficznych Lednickiego Parku Krajobrazowego, w: Wstęp do paleoekologii, s. 11-34; M. Makohonienko, Przyrodnicza historia Gniezna, Poznań-Bydgoszcz 2000 (Prace Zakładu Biogeografii i Paleoekologii); tenże, Materiały do postglacjalnej historii roślinności okolic Lednicy. Część II: Badania palinologiczne osadów Jeziora Lednickiego - rdzeń 1/86 i Wal/87, w: Wstęp do
}

gatunek wykorzystywano w celach opałowych, co pośrednio sugerują także wyniki naszych analiz. $\mathrm{Z}$ drugiej strony obszary z dominacją graba, które występowały na żyznych ziemiach, mogły być zajmowane i przekształcane w tereny uprawowe.

Opisywane przez nas zjawisko koresponduje z wynikami innych badań palinologicznych. Opublikowane dotąd diagramy pyłkowe z Wielkopolski, a w szczególności Wysoczyzny Gnieźnieńskiej, również pokazują wyraźny spadek udziału procentowego pyłku graba, który łączono z końcem kryzysu demograficznego po wędrówce ludów ${ }^{19}$. Brak precyzyjnie opracowanej chronologii nie pozwala jednak na ustalenie dokładnych ram czasowych tego zjawiska. Daty konwencjonalne ze stanowiska Jezioro Skrzetuszewskie każą natomiast łączyć spadek udziału procentowego pyłku graba $\mathrm{z}$ nasileniem presji człowieka już po 400 r. $(+/-100)^{20}$.

paleoekologii, s. 63-70; M. Makohonienko, M. Makowiecki, Rozwój krajobrazu kulturowego w otoczeniu jeziora Lednica na Wysoczyźnie Gnieźnieńskiej, „Landform Analysis”, 16, 2011, s. 32-38.

${ }_{19}^{19}$ Tamże.

${ }^{20}$ K. Tobolski, Dotychczasowy stan, s. 11-34. 
Prezentowane przez nas wyniki wskazują precyzyjniej, że w okolicy stanowiska Kazanie gwałtowne odlesienia zachodziły od 1025 r. $(+/-21)$, co świadczy, że nastąpił wówczas na tym obszarze początek intensyfikacji presji osadniczej we wczesnym państwie piastowskim. Mając na uwadze, że ówczesne lasy miały charakter puszczy, należy to uznać za zjawisko charakterystyczne dla całego regionu. Podobne dane $\mathrm{z}$ położonych niedaleko Jeziora Skrzetuszewskiego $(11 \mathrm{~km}$ w linii prostej) i Ostrowa Lednickiego (9 km w linii prostej), który miał wówczas status nadrzędnego ośrodka obronnego i administracyjnego, każą przyjąć, że obszary te prezentowały zbliżoną odpowiedź na zaburzenia przyrodnicze związane $\mathrm{z}$ działalnością człowieka.

Choć trzebież grądów niewątpliwie została udokumentowana w źródłach paleoekologicznych, to obraz tego procesu został prawdopodobnie zmodyfikowany przez lokalną sukcesję roślinności na torfowisku (rozprzestrzenienie się w jego otoczeniu sosny). Odlesienia te mogły więc następować stopniowo, a nie gwałtownie, jak sugerują dane pyłkowe.

Widoczny spadek udziału procentowego roślin uprawnych i chwastów w latach $1025(+/-21)-1060(+/-24)$ może być łączony $\mathrm{z}$ wydarzeniami natury politycznej. Zgodnie z przekazem Galla Anonima i źródeł z krajów sąsiednich za panowania Mieszka II nastąpił kryzys państwa. Jednym $z$ jego objawów było tymczasowe objęcie władzy przez Mieszkowego brata-Bezpryma, wprowadzonego w $1031 \mathrm{r}$. na tron dzięki militarnemu wsparciu ze strony Jarosława Mądrego. Zajął on m.in. Gniezno i mimo stosunkowo szybkiego powrotu Mieszka II Wielkopolska była przez dwie dekady areną wojen i niepokojów społecznych. Najpierw w 1039 r. najechał ją czeski książę Brzetysław, po czym krajem wstrząsnęło tajemnicze powstanie. W wyniku tych wydarzeń zniszczeniu uległy siedziby biskupie w Gnieźnie i Poznaniu ${ }^{21}$, a stanowisko, z którego zaczerpnęliśmy materiał do analiz, znajduje się w pobliżu drogi łączącej obie najważniejsze siedziby książęce i biskupie, nazywanej w późnym średniowieczu magna via ${ }^{22}$. Inne, przyrodnicze wytłumaczenie spadku udziału procentowego roślin uprawnych i chwastów mówi o większej produkcji pyłku przez brzozę (rodzaj produkujący ogromne ilości pyłku ${ }^{23}$ ), która rozprzestrzeniła się na skutek zarastania jeziora. Jest to takson pionierski, światłożądny i wysoko tolerancyjny na czynniki klimatyczne i glebowe, wobec czego często stanowi pierwsze stadium sukcesji ${ }^{24}$. Analiza makroszczątków ${ }^{25}$ pokazuje, że w latach $990(+/-24)-$ $1120(+/-27)$ notowana była w osadach także zwiększona obecność owoców brzóz (Betula pubescens i Betula pendula), co informuje, że prawdopodobnie występowały lokalnie przy krawędzi jeziora, z uwagi na bezpośrednie sąsiedztwo zbiornika ${ }^{26}$.

\section{Intensyfikacja rolnictwa}

Podstawowa struktura osadnicza w promieniu $5 \mathrm{~km}$ od badanego stanowiska ukształtowała się w późnym średniowieczu. Stanowiło ją 21 miejscowości wchodzących w skład późniejszego powiatu gnieźnieńskiego (18 osad) i poznańskiego (3). Pierwsze pisane wzmianki dotyczą wsi Górki i Jagodna i pochodzą już z 1170 r. ${ }^{27}$, a pozostałe odnotowano w źródłach

\footnotetext{
${ }^{21}$ Anonima tzw. Galla Kronika, czyli Dzieje książąt i władców polskich, wyd. K. Maleczyński, Kraków 1952, s. 4.

${ }_{22}$ T. Związek, Drogi, w: Wielkopolska w drugiej połowie XVI wieku, cz. 2: Komentarz, indeksy, red. K. Chłapowski, M. Słoń, Warszawa 2017 (Atlas historyczny Polski. Mapy szczegótowe XVI wieku, 4), s. 272.

${ }^{23}$ M. Ralska-Jasiewiczowa i in., Betula L. - Birch, w: Late Glacial and Holocene history of vegetation in Poland based on isopollen maps, ed. M. Ralska-Jasiewiczowa i in., Kraków 2004, s. 57-68.

${ }^{24} \mathrm{~J} . \mathrm{B}$. Faliński, Pioneer woody species and their role in the regeneration and secondary succession, w: Dynamics and conservation of the Pomeranian vegetation, ed. W. Fattynowicz, M. Latałowa, J. Szmeja, Gdańsk-Poznań 1997, s. 33-54.

${ }^{25}$ Wyniki analiz nie zostały zamieszczone w artykule.

${ }^{26}$ H.H. Birks, Plant macrofossil introduction, w: Encyclopedia of Quaternary science, ed. S.A. Elias, Amsterdam 2007, s. 2266-2288.

${ }^{27}$ Joannis Dlugossi Annales seu Cronicae incliti Regni Poloniae, lib. 5-6, Warszawa 1975, s. 94. Pod datą 1170 Długosz podaje informację 0 ufundowaniu w Poznaniu szpitala joannitów, uposażonego m.in. we wsie Jagodno i Górka. Szerzej na ten temat: A. Gąsiorowski, Najstarsze
} 


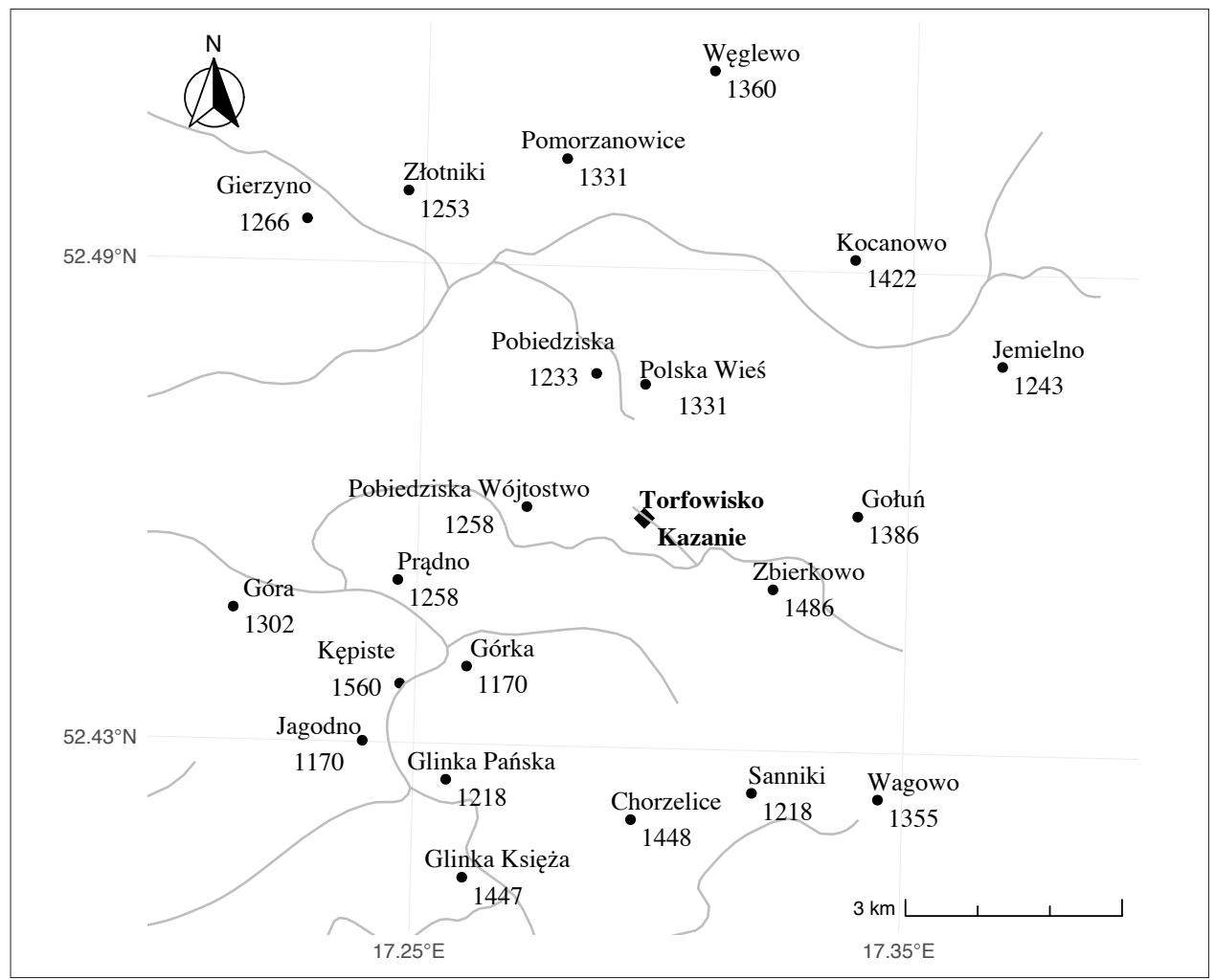

Mapa 1. Daty pierwszych pisemnych wzmianek o miejscowościach w pobliż torfowiska Kazanie.

Żródto: oprac. własne na podstawie stownika historyczno-geograficznego Wielkopolski

historycznych z XIII-XV w. (mapa 1). Większość z nich została zapewne założona na prawie polskim, a z czasem przeorganizowano je w myśl prawa niemieckiego ${ }^{28}$. Same Pobiedziska lokowano na prawie niemieckim ok. 1258 r. ${ }^{29}$ Wdrażanie nowych

dokumenty poznańskiego domu joannitów, „Studia Źródłoznawcze”, 8, 1963, s. 83-95; tenże, Najstarsze dokumenty poznańskiego domu joannitów. Dokończenie, „Studia Źródłoznawcze”, 9, 1964, s. 47-60.

${ }^{28}$ K. Stefański, Wsie na „prawie niemieckim" w Wielkopolsce w latach 1333-1370, „Roczniki Historyczne”, 37, 1971, s. 1-36.

${ }^{29}$ Kodeks dyplomatyczny Wielkopolski, t. 1, wyd. F. Piekosiński, Poznań 1877, nr 346. Dokument Przemysła I potwierdzający sprzedaż wójtostwa w Pobiedziskach uznany został przez Franciszka Sikorę za falsyfikat, ale zarówno w literaturze regionalnej, jak i opracowaniach historii miast ich lokację datuje się ok. 1258 r. Zob. F. Sikora, Dokumenty i kancelaria Przemysta I oraz Bolestawa Pobożnego 1239-1270 na tle wspótczesnej dyplomatyki wielkopolskiej, Wrocław 1969, s. 186; B. Frankiewicz, Z dziejów ziemi pobiedziskiej, Pobiedziska 1990, s. 18; M. Kustra, Pobiedziska wraz z okolicą w średniowieczu i u progu nowożytności, Poznań-Pobiedziska-Gniezno 2013, s. 179; M. Bogucka, H. Samsonowicz, Dzieje miast i mieszczaństwa w Polsce przedrozbiorowej, Wrocław 1986, s. 63. zasad wiązało się z oczynszowaniem gospodarstw chłopskich i zestandaryzowaniem ich wielkości, a także z rozwojem elementów samorządu wiejskiego. Modernizacja na poziomie organizacyjno-technicznym: regulacja pól, wprowadzenie trójpolówki, szersze użycie ciężkiego pługa i żelaznej brony, a także konieczność urynkowienia gospodarki chłopskiej, prowadziła z kolei do zwiększenia produkcji rolniczej i hodowli. Możemy przyjąć, że intensyfikacja tych procesów nastąpiła po najeździe krzyżackim z 1331 r., w wyniku którego zniszczone zostały miasto Pobiedziska i okoliczne wsi (m.in. Polska Wieś i Pomorzany), o czym wiemy z zeznań świadków z Pobiedzisk na procesie polsko-krzyżackim w 1339 r. $^{30}$

\footnotetext{
${ }^{30}$ Lites ac Res gestae inter Polonos ordinemque Cruciferorum, t. 1, wyd. 2, Poznań 1890, s. 362-363.
} 


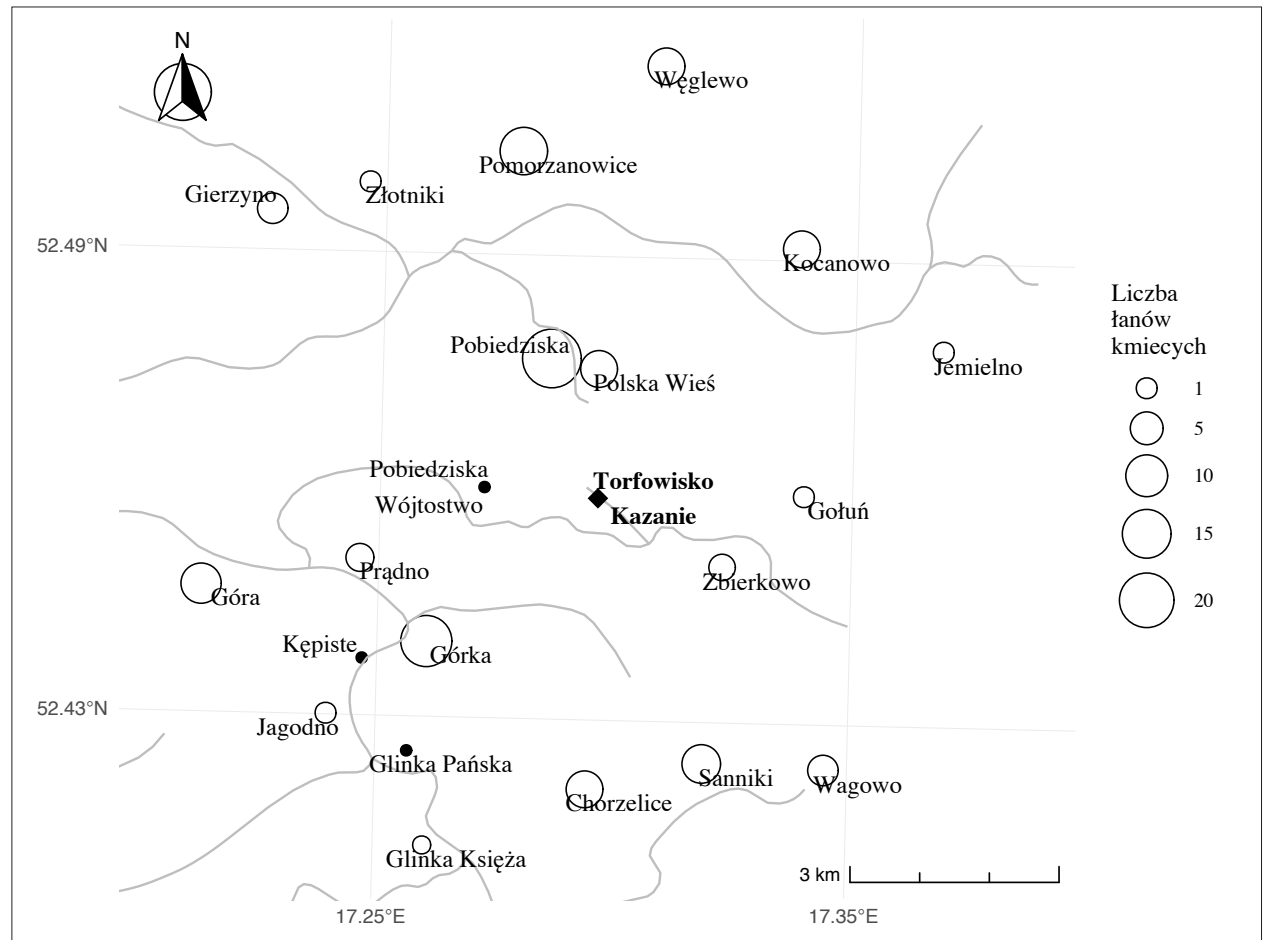

Mapa 2. Liczba łanów osadzonych w miejscowościach sąsiadujących z torfowiskiem Kazanie w latach 1563-1567. Żródto: oprac. własne

Jak pokazują dane pyłkowe, gwałtowny rozwój rolnictwa rozpoczął się w roku $1420(+/-18)$ i trwał aż do $1600(+/-19)$. Zwłaszcza w odniesieniu do drugiej połowy XVI i początku XVII w. dysponujemy szeregiem źródeł dokumentujących aktywność gospodarczą w postaci rejestrów podatku łanowego i lustracji dóbr królewskich ${ }^{31}$. Można dzięki nim określić

\footnotetext{
${ }^{31}$ Rejestr poborowy województwa kaliskiego 1618-1620, wyd. A.J. Parczewski, Warszawa 1879; M. Gochna, M. Słoń, U. Zachara-Związek, Rejestr poborowy powiatu gnieźnieńskiego 1564 r., w: Atlas historyczny Polski. Rejestry poborowe województwa kaliskiego w XVI w., red. M. Słoń, 2015 (Atlas Źródeł i Materiałów do Dziejów Dawnej Polski, 2 , http://atlasfontium.pl/index.php?article = gniezno_1564, dostęp: 15 lipca 2019); K. Chłapowski, M. Słoń, U. Zachara-Z̄wiązek, Rejestr poborowy powiatu gnieźnieńskiego 1565 r., w: Atlas historyczny Polski. Rejestry poborowe województwa kaliskiego w XVI w., red. M. Słoń, 2015 (Atlas Źródeł i Materiałów do Dziejów Dawnej Polski, 2 http://atlasfontium.pl/index.php?article=gniezno_1565, dostęp: 15 lipca 2019); A. Dunin-Wąsowicz, U. Zachara-Związek, T. Związek, Rejestr poborowy powiatu poznańskiego $1563 \mathrm{r}$., w: Atlas historyczny Polski. Rejestry poborowe województwa poznańskiego w XVI w., red. M. Stoń, 2015 (Atlas Źródeł i Materiałów do Dziejów Dawnej Polski, 3, http://atlasfontium.pl/index.php?article= poznan_1563, dostęp:
}

areał uprawianej ziemi i dokonać kalkulacji liczby ludności. W latach 1563-1567 chłopi z 21 miejscowości w pobliżu torfowiska Kazanie uprawiali 118 łanów ziemi (1 łan - ok. 17 ha). Należy do tego doliczyć grunty w dyspozycji folwarków, ale w związku z nierejestrowaniem ziemi folwarcznej w źródłach podatkowych nie wiemy, ile ich było. Lustracja dóbr królewskich wymienia tylko 4 większe gospodarstwa tego typu, należące do starostwa pobiedziskiego: w Pobiedziskach, Pobiedziskach-Wójtostwie, Polskiej Wsi

\footnotetext{
15 lipca 2019); K. Chłapowski, M. Słoń, U. Zachara-Związek, Rejestr poborowy powiatu poznańskiego 1567 r., w: Atlas historyczny Polski. Rejestry poborowe województwa poznańskiego w XVI w., red. M. Słoń, 2015 (Atlas Źródeł i Materiałów do Dziejów Dawnej Polski, 3, http:// atlasfontium.pl/index.php?article = poznan 1567, dostęp 15 lipca 2019); Lustracja województw wielkopolskich i kujawskich 1564-1565, cz. 1, wyd. A. Tomczak, C. Ohryzko-Włodarska, J. Włodarczyk, Bydgoszcz 1961; Lustracja województw wielkopolskich i kujawskich 1659-1665, cz. 1: Województwa poznańskie i kaliskie, wyd. C. Ohryzko-Włodarska, Wrocław-Warszawa-Kraków-Gdańsk 1978.
} 
i Węglewie, jednak możemy być pewni, że we wsiach należących do szlachty było ich więcej.

Przyjmując przeliczniki ustalone w literaturze z zakresu demografii historycznej, możemy skalkulować liczbę ludności 20 wsi na około 950 osób $^{32}$, do których należałoby doliczyć mieszkańców miasteczka Pobiedziska w liczbie 1000-1100, żyjących w 187 domach $^{33}$. Populacja ta musiała być wówczas dominującą siłą kształtującą środowisko. Świadczy o tym wyraźny wzrost udziału wskaźników antropogenicznych, np. pyłku roślin uprawnych i chwastów czy pyłku roślin siedlisk ruderalnych, notowanych szczególnie w latach 1420 (+/-18) 1600 (+/-19). Oprócz wyrębywania lasów liściastych występujących na żyznych ziemiach i zastępowania ich uprawami widoczny był trend zwiększania powierzchni łąk i pastwisk, a także towarzyszących im siedlisk antropogenicznych. Dla tego okresu, a szczególnie lat $1480(+/-19)-1580$ (+/-19), odnotowany został wzrost udziału węgli mikroskopowych, co pośrednio sugeruje wzmożoną aktywność człowieka, np. wykorzystanie zasobów lasu jako materiału opałowego nie tylko w domach, ale również w urządzeniach preindustrialnych, jak browary, huty i kuźnice ${ }^{34}$. Z danych

\footnotetext{
${ }^{32}$ K. Boroda, P. Guzowski, Przeliczniki demograficzne w szacunkach zaludnienia terenów wiejskich w Królestwie Polskim w drugiej potowie XVI wieku, „Przeszłość Demograficzna Polski”, 37 (2), 2015, s. 53-75.

${ }^{33}$ Lustracja województw wielkopolskich i kujawskich 1564-1565, s. 278; P. Guzowski, R. Poniat, Przeliczniki demograficzne w szacunkach zaludnienia miast w Królestwie Polskim w drugiej połowie XVI wieku, „Przeszłość Demograficzna Polski”, 37 (2), 2015, s. 77-93.

${ }^{34} \mathrm{C}$. Whitlock, C. Larsen, Charcoal as a fire proxy, w: Tracking environmental change using lake sediments, ed. J.P. Smol, H.J.B. Birks, W.M. Last, Dordrecht 2001, s. 75-97; W. Tinner, F.S. Hu, Size parameters, size-class distribution and area-number relationship of microscopic charcoal. Relevance for fire reconstruction, "The Holocene", 13 (4), 2003, s. 499-505; C. Whitlock i in., Paleoecological perspectives on fire ecology. Revisiting the fire-regime concept, ,"The Open Ecology Journal", 3, 2010, s. 6-23; K. Marcisz i in., Long-term hydrological dynamics and fire history over the last 2000 years in CE Europe reconstructed from a high-resolution peat archive, „Quaternary Science Reviews", 112, 2015, s. 138-152; E. Dietze $\mathrm{i}$ in., Holocene fire activity during low-natural flammability periods reveals scale-dependent cultural human-fire relationships in Europe, „Quaternary Science Reviews", 201, 2018, s. 44-56.
}

pyłkowych wynika, że pod koniec XVI w. silnie wytrzebione lasy, które przez setki lat zmagały się z presją człowieka i w pewien sposób były przez niego umiejętnie zarządzane, zostały ostatecznie kompletnie przekształcone. Kilkusetletnia presja gospodarcza człowieka doprowadziła zatem do prawie całkowitego zaniku wielogatunkowych lasów liściastych, które zostały zastąpione głównie przez lasy sosnowe.

\section{Kryzys społeczno-ekonomiczny}

Analiza źródeł przyrodniczych wskazuje, że między 1620 (+/-20) a 1800 r. (+/-40) doszło do regresu osadnictwa. Stopniowa wycinka, której nasilenie przypadło na przełom XVI i XVII w., przyczyniła się do otwarcia krajobrazu, co ułatwiało wkroczenie na porolne ziemie leżące odłogiem sośnie. Można by zatem przypuszczać, że z uwagi na nadprodukcję pyłku sosny początkowy sygnał o regresie osadnictwa mógł być nieco zniekształcony i zaczęło się ono kilkadziesiąt lat później, tj. w drugiej połowie XVII w. Widoczny jest też jednak znaczny spadek udziału pyłku roślin uprawnych i chwastów w ciagu zaledwie dwudziestu lat (z 4 proc. w roku $1600(+/-18)$ do 1,5 proc. w $1620(+/-20)$, co niewątpliwie musiało być wywołane spadkiem ogólnej powierzchni areałów uprawnych, i dopiero po tym okresie następuje gwałtowny wzrost udziału pyłku sosny. Zgadza się to z danymi historycznymi, które przekonują, że początki kryzysu widać już u zarania trzeciej dekady XVII w. W porównaniu do opisanego wyżej wcześniejszego okresu rejestry podatkowe z $1618 \mathrm{r}$. notują w 16 wsiach (o których mamy dane) spadek areału upraw chłopskich ze 102 łanów do 67,535. Zmniejszenie powierzchni ziemi uprawnej w rękach chłopskich o ponad 30 proc. mogło być co prawda zrekompensowane rozrostem folwarków, które powstawały i rozwijały się w Wielkopolsce najczęściej na łanach

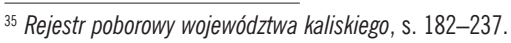


pustych $^{36}$, ale zarówno gospodarka chłopska, jak folwarczna mocno ucierpiały w wyniku zniszczeń wojennych, epidemii i kryzysu gospodarczego związanych z potopem szwedzkim na początku drugiej połowy XVII w. Władysław Rusiński szacował na podstawie danych z lustracji spadek liczby ludności rolnej w województwie poznańskim o 46,1 proc., a w kaliskim - aż o 62,6 proc. ${ }^{37} \mathrm{~W}$ przypadku miejscowości w pobliżu naszego stanowiska był on jeszcze większy. Na podstawie rejestru pogłównego z 1673 r. liczbę mieszkańców powyżej dziesiątego roku życia można ustalić na $460^{38}$. Gdy doszacujemy brakujące dzieci, które stanowiły ok. 30 proc. ówczesnego społeczeństwa $^{39}$, stan populacji 21 najbliższych stanowisku miejscowości w drugiej połowie XVII w. możemy określić na ok. 650 osób. W stosunku do okresu sto lat wcześniejszego mamy więc do czynienia ze spadkiem liczby ludności o 67,5 proc. Lustratorzy opisujący w tym czasie Pobiedziska i zlokalizowane wokół nich dobra królewskie stwierdzili: „To starostwo, tak miasteczko, jako i wsi, iż na wielkim gościńcu zostają, tedy przez częste przechodzenie nieprzyjaciela, ogień, wojska cesarza JM, ale osobliwie przez codzienne przechodzącego żołnierza naszego i nieznośne chleba zimowego po kilkakroć wyciaganie, tak jako się opisało, popustoszone są" ${ }^{30}$. Mimo że ostatnie dekady XVII w. były w Wielkopolsce stosunkowo spokojne, to początek następnego stulecia przyniósł zmagania trzeciej wojny północnej oraz kolejne zniszczenia nieodbudowanej

${ }^{36} \mathrm{~J}$. Topolski, Przyczyny powstania i rozwój folwarku pańszczyźnianego w: Dzieje Wielkopolski, t. 1: Do roku 1793, red. J. Topolski, Poznań 1969, s. 452.

${ }^{37}$ W. Rusiński, Straty i zniszczenia w czasie wojny szwedzkiej (1655-60) oraz jej skutki na obszarze Wielkopolski, w: Polska w okresie drugiej wojny pótnocnej, t. 2, red. K. Lepszy i in., Warszawa 1957, s. 276.

${ }^{38}$ Archiwum Główne Akt Dawnych, Archiwum Skarbu Koronnego I, 68 (rejestr województwa poznańskiego) i ASK I, 74 (rejestr województwa kaliskiego).

${ }^{39}$ I. Gieysztorowa, Wstęp do demografii staropolskiej, Warszawa 1976 , s. 196.

${ }^{40}$ Lustracja województw wielkopolskich i kujawskich 1659-1665, cz. 1, s. 138. gospodarki i społeczeństwa przez wojska saskie, szwedzkie, moskiewskie i koronne. Podejmowano co prawda próby sprowadzenia w okolice Pobiedzisk osadników holenderskich, śląskich i niemieckich oraz przeorganizowania gospodarki i zastąpienia pańszczyzny czynszami ${ }^{41}$, ale nie przyniosły one przełomu gospodarczego, o czym świadczą także źródła przyrodnicze. Dla całego okresu opisywanego kryzysu społeczno-ekonomicznego utrzymuje się w próbkach niski udział pyłku roślin uprawnych i chwastów. Podczas gdy jeszcze w 1600 r. (+/-18), przed widocznym załamaniem, udział ten wynosił aż 4 proc., to w $1715(+/-40)$ już zaledwie 0,5 proc., by w $1800(+/-40)$ sięgnąć 1,3 proc. Widoczny jest także niższy udział pyłku roślin ruderalnych, traw oraz wskaźnika łąk i pastwisk. Co więcej, spadek udziału węgli mikroskopijnych notowany był mniej więcej od 1640 r. (+/-23) i trwał aż do końca $1800(+/-40)$. Krótkotrwały wzrost krzywej węli mikroskopijnych widoczny był natomiast w 1715 r. (+/-40), niewykluczone że w związku z pożarami wywołanymi przez działania wojenne lub inne nieszczęścia, jak odnotowany w 1735 r. wielki pożar trzech browarów w Pobiedziskach, w którym spłonęły też domy mieszkalne ${ }^{42}$. W końcowym okresie wieku XVIII widoczna jest regeneracja lasów z dominacją sosny, która szybko zadomowiła się na obszarach porolnych. Manifestuje to wysoki udział pyłku sosny, który w 1770 r. (+/-40) wzrósł do 85,5 proc., osiagając swoje maksimum.

\footnotetext{
${ }^{41}$ K.J. Hładyłowicz, Zmiany krajobrazu i rozwój osadnictwa w Wielkopolsce, Lwów 1932, s. 122-124. Szerzej 0 osadnictwie olęderskim w Polsce: J.T. Baranowski, Wsie holenderskie na ziemiach polskich, „Przegląd Historyczny”, 19, 1915, s. 65-82; W. Rusiński, Osady tzw. Olędrów w dawnym województwie poznańskim, Poznań-Kraków 1947; Z. Chodyła, Zarys dziejów osadnictwa olęderskiego w Polsce 1547-1864, w: Olędry. Przestrzenie wokót nas, Poznań 2006, s. 32-71; M. Targowski, Osadnictwo olęderskie w Polsce - jego rozwój i specyfika, w: Olędrzy - osadnicy znad Wisty. Sąsiedzi bliscy i obcy, red. A. Pabian, M. Targowski, Toruń 2016, s. 11-26.

${ }^{42}$ Archiwum Państwowe w Poznaniu, Komisja Skarbowa Poznańska 44 , k. 56-56v.
} 


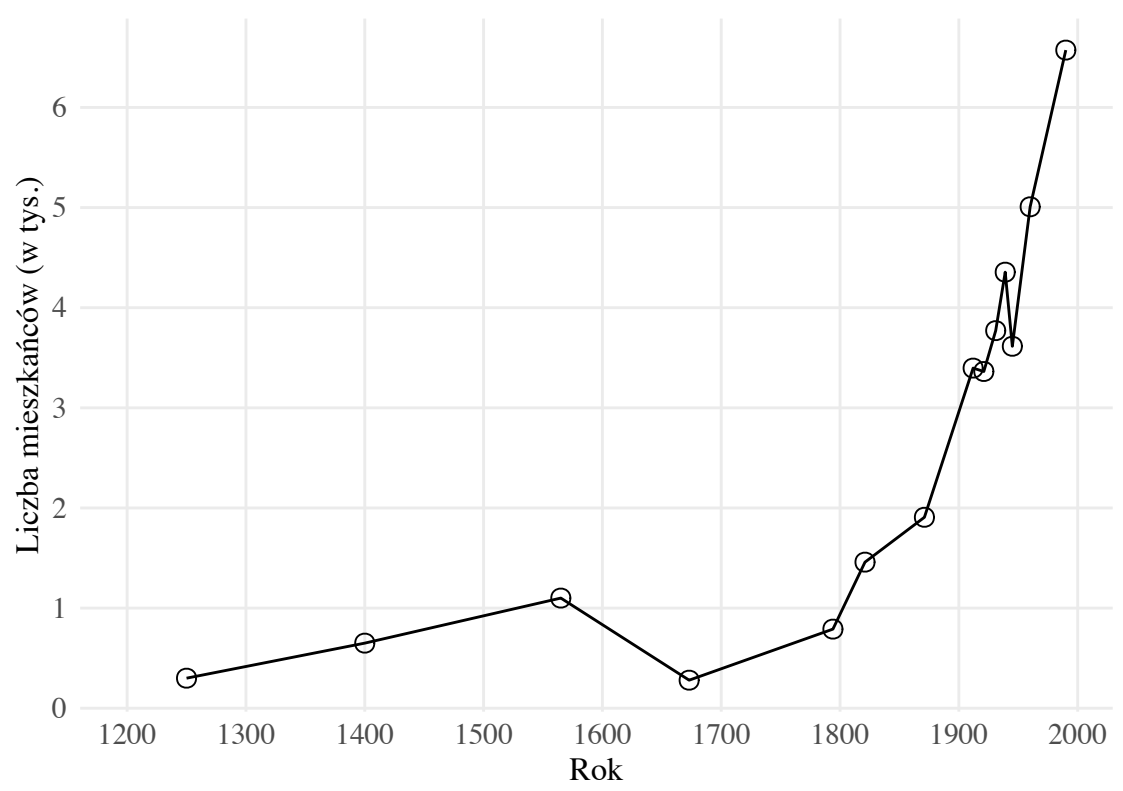

Wykres 2. Liczba mieszkańców Pobiedzisk w XIII-XX w.

Źródto: oprac. własne

\section{Dzieje najnowsze}

Uwłaszczenie, napływ osadników niemieckich i zmiany organizacyjne w handlu (giełdy towarowe i spółdzielnie) następujące w ciągu XIX i na początku XX w. przyczynity się do wzrostu lokalnej produkcji rolniczej i zwiększenia populacji (wykres 2$)^{43}$. Gwałtowny spadek krzywej udziału pyłku roślin uprawnych oraz łąk i pastwisk przypada na okres pierwszej wojny światowej. W tej fazie widoczny jest również nieznaczny spadek udziału procentowego pyłku Brassicacea, emitowanego m.in. przez rzepak (Brassicanapus), a także kapustę warzywną (Brassicaoleracea), której odmiany mogły być wykorzystywane jako rośliny pastewne, być może wprowadzane wcześniej stopniowo jako nowe uprawy $^{44}$. Po opisanym spadku następuje ponowny szybki wzrost udziału pyłku

$\overline{{ }^{43} \text { B. Frankiewicz, Z dziejów, s. } 51 .}$.

${ }^{44} \mathrm{M}$. Theuerkauf $\mathrm{i}$ in., Effects of changes in land management practices on pollen productivity of open vegetation during the last century derived from varved lake sediments, „The Holocene”, 25 (5), 2015, s. 733-744. roślin uprawnych i chwastów, a także łąk i pastwisk. Krzywa udziałów wskaźników roślin uprawnych i chwastów osiąga swoje apogeum (26 proc.) w 1939 r. (+/-8), po czym zaczyna gwałtownie spadać, do jedynie 9 proc. w 1955 r. (+/-7). Zasadne jest zatem stwierdzenie, że to działania wojenne destrukcyjnie wpłynęły na sytuację miejscowej gospodarki rolnej podczas pierwszej wojny światowej, a w przypadku drugiej należy dodać straty populacji związane z zagładą ludności żydowskiej, eksterminacją oraz masowym wywożeniem na roboty do Niemiec polskiej ludności Pobiedzisk i okolic ${ }^{45}$.

Dominacja zbóż mogła być stopniowo zastępowana przez zwiększający się areał upraw rzepaku, co szczególnie widać w latach $1955(+/-7)$ - $1990(+/-3)$, gdy stanowił on min. 0,5 proc., a maks. 4,7 proc., a także w kilkunastu ostatnich latach, gdy dochodził do 4,3 proc. Dane te thumaczą częściowo spadek wskaźników pyłku

${ }^{45}$ B. Frankiewicz, Z dziejów, s. 106-124. 
roślin uprawnych i potwierdzają ogólne krajowe trendy związane z uprawą rzepa$\mathrm{ku}^{46}$. Wobec minionego stulecia można też mówić o znacznych uprawach roślin owadopylnych z rodziny kapustowatych, o czym świadczy udział ich pyłku w ogólnym obrazie sięgający kilku procent.

Od 1952 r. (+/-7) poza wymienionymi zmianami dostrzegalna jest jeszcze większa presja człowieka, objawiająca się, jak można odczytać z diagramu pyłkowego, zwiększoną powierzchnią łąk i pastwisk, szczególnie do roku 1985 (+/-2), czy zwiększoną aktywnością pożarową osiągającą maksimum w $1959(+/-3)$, co lokalnie mogło być też związane z wypalaniem traw. Postępujący spadek udziału pyłku roślin uprawnych i chwastów (głównie zbóż) w ostatnich latach koresponduje $\mathrm{z}$ większym, także planowanym zalesieniem obszaru, a prawdopodobnie i rosnącą rolą rzepaku.

\section{Podsumowanie}

Wyniki analiz pyłkowej oraz węgli mikroskopijnych poza możliwością klasycznej rekonstrukcji roślinności oraz identyfikacji pożarów i aktywności osadniczej dostarczają precyzyjnych danych o przekształceniach środowiska, w którym człowiek odgrywał główną rolę. Głównym czynnikiem wpływającym na lokalne środowisko były zatem historyczne zmiany społeczno-gospodarcze, których ślady możemy odnaleźć w źródłach kopalnych. Jak pokazują analizy paleośrodowiskowe ze stanowiska Kazanie wsparte źródłami historycznymi, zmiany te stanowią istotny przykład wzajemnego oddziaływania między środowiskiem i człowiekiem, który od tysiącleci przekształcał je dla swoich potrzeb. Opracowanie dla danych paleoekologicznych stanowiska wysokiej jakości chronologii bezwzględnej rzuca na nie nowe światło zarówno w kontekście przyrodniczym, jak i historycznym; umożliwia także uszczegółowienie i korektę

\footnotetext{
${ }^{46}$ E. Arseniuk, T. Oleksiak, Polski rzepak. Dorobek badawczy i hodowlany, Radzików 2004.
}

opublikowanych dotychczas wyników prac sondażowych w mikroskali ${ }^{47}$. W pracy tej wykazano, że:

- do gwałtownych odlesień doszło w latach $1025(+/-21)-1090(+/-26)$, co dokumentuje gwałtowny spadek udziału pyłku graba (może to świadczyć o celowym karczowaniu lasu przez lokalną społeczność w okresie kształtowania się monarchii wczesnopiastowskiej);

- nasilona presja na środowisko związana z rewolucją gospodarczą trwała od początku XV do początku XVII w. i to wówczas ukształtowała się zasadnicza sieć osadnicza i nastąpił rozwój miejscowej populacji;

- ograniczenie presji człowieka na skutek gwałtownego kryzysu społeczno-ekonomicznego związanego z działaniami wojennymi i epidemiami od połowy XVII w. doprowadziło do rozwoju lasów z dominacją sosny. Jak pokazuje analiza pyłkowa, przy niewielkiej presji człowieka rozwijały się one ok. 100-150 lat;

- podczas pierwszej i drugiej wojny światowej doszło do gwałtownego spadku udziału pyłku roślin uprawnych, co ma związek m.in. z załamaniem się w tych okresach miejscowej gospodarki rolnej;

- okres powojenny cechował się intensywnym użytkowaniem ziemi, m.in. wprowadzeniem nowych odmian upraw czy zwiększeniem powierzchni przeznaczonej pod pastwiska.

Wyniki przedstawione $\mathrm{w}$ artykule stanowią dowód, że analizy paleoekologiczne i dane historyczne wzajemnie się uzupełniają. W związku z tym, że zmiany społeczno-gospodarcze mają swoje odzwierciedlenie w środowisku (np. zmiany systemu użytkowania ziemi), współpraca historyków, archeologów i paleoekologów

\footnotetext{
${ }^{47}$ A. Izdebski i in., On the use of palynological data; A. Izdebski i in., Historia.
} 
dostarcza nowej generacji danych dotyczących działalności człowieka. Ograniczenia danych paleoekologicznych mogą być częściowo eliminowane przez zastosowanie źródeł historycznych. Interpretacja wpływu człowieka na środowisko i jego aktywności gospodarczej czy osadniczej sięga zatem tak daleko, jak początki akumulacji osadów biogenicznych. Jej wiarygodność wzrasta wraz z dostępem do źródeł historycznych

\section{Bibliografia}

\section{Źródła publikowane}

Anonima tzw. Galla Kronika, czyli Dzieje książąt i wtadców polskich, wyd. K. Maleczyński, Kraków 1952.

Chłapowski K., Słoń M., Zachara-Związek U., Rejestr poborowy powiatu gnieźnieńskiego 1565 r., w: Atlas historyczny Polski. Rejestry poborowe województwa kaliskiego w XVI w., red. M. Słoń, 2015 (Atlas Źródeł i Materiałów do Dziejów Dawnej Polski, 2, http:// atlasfontium.pl/index.php?article=gniezno_1565, dostęp: 15 lipca 2019).

Chłapowski K., Słoń M., Zachara-Związek U., Rejestr poborowy powiatu poznańskiego 1567 r., w: Atlas historyczny Polski. Rejestry poborowe województwa poznańskiego $w$ XVI w., red. M. Słoń, 2015 (Atlas Źródeł i Materiałów do Dziejów Dawnej Polski, 3, http://atlasfontium.pl/index.php?article=poznan_1567, dostęp 15 lipca 2019).

Dunin-Wąsowicz A., Zachara-Związek U., Związek T., Rejestr poborowy powiatu poznańskiego 1563 r., w: Atlas historyczny Polski. Rejestry poborowe województwa poznańskiego w XVI w., red. M. Słoń, 2015 (Atlas Źródeł i Materiałów do Dziejów Dawnej Polski, 3, http://atlasfontium.pl/index.php?article=poznan_1563, dostęp: 15 lipca 2019).

\section{Literatura}

Archeologiczne Zdjęcie Polski-metoda i doświadczenia. Próba oceny, red. D. Jaskanis, Warszawa 1996.

Arseniuk E., Oleksiak T., Polski rzepak. Dorobek badawczy $i$ hodowlany, Radzików 2004.

Bal M.C., Pelachs A., Perez-Obiol R., Julia R., Cunill R., Fire history and human activities during the last 3300 calyr BP in Spain's Central Pyrenees. The case of the Estany de Burg, „Palaeogeography, Palaeoclimatology, Palaeoecology”, 300 (1-4), 2011, s. 179-190.

Baranowski J.T., Wsie holenderskie na ziemiach polskich, „Przegląd Historyczny”, 19, 1915, s. 65-82. (i archeologicznych) dla danego obszaru, co daje szansę skonfrontowania danych. Z tego powodu okres ostatniego tysiąclecia (a zwłaszcza 600-700 lat) stanowi w przypadku Wielkopolski doskonałe pole do wspólnego prowadzenia badań nad przełomami gospodarczymi przez historyków i paleoekologów, a przynosząca obiecujące efekty współpraca interdyscyplinarna kontynuowana będzie w przyszłości.

Gochna M., Słoń M., Zachara-Związek U., Rejestr poborowy powiatu gnieźnieńskiego 1564 r., w: Atlas historyczny Polski. Rejestry poborowe województwa kaliskiego wXVI w. red. M. Słoń, 2015 (Atlas Źródeł i Materiałów do Dziejów Dawnej Polski, 2, http:// atlasfontium.pl/index.php?article=gniezno_1564, dostęp: 15 lipca 2019).

Joannis Dlugossi Annales seu Cronicae incliti Regni Poloniae, lib. 5-6, Warszawa 1975.

Kodeks dyplomatyczny Wielkopolski, t. 1, wyd. F. Piekosiński, Poznań 1877.

Lites ac Res gestae inter Polons ordinemque Cruciferorum, t. 1, wyd. 2, Poznań 1890.

Lustracja województw wielkopolskich i kujawskich 1564-1565, cz. 1, wyd. A. Tomczak, C. Ohryzko-Włodarska, J. Włodarczyk, Bydgoszcz 1961.

Lustracja województw wielkopolskich $i$ kujawskich 16591665, cz. 1: Województwa poznańskie $i$ kaliskie, wyd. C. Ohryzko-Włodarska, Wrocław-Warszawa-Kraków-Gdańsk 1978.

Rejestr poborowy województwa kaliskiego 1618-1620, wyd. A.J. Parczewski, Warszawa 1879.

Behre K.E., The interpretation of anthropogenic indicators in pollen diagrams, "Pollen et Spores”, 23, 1981, s. 225-245.

Berglund B.E., Ralska-Jasiewiczowa M., Pollen analysis, w: Handbook of Holocene palaeoecology and palaeohydrology, ed. B.E. Berglund, Chichester-New YorkBrisbane-Toronto-Singapore 1986, s. 455-484.

Birks H.H., Plant macrofossil introduction, w: Encyclopedia of Quaternary science, ed. S.A. Elias, Amsterdam 2007, s. 2266-2288.

Bitušík P., Trnková K., Chamutiová T., Sochuliaková L., Stoklasa J., Pipík R., Szarlowicz K., 
Szacilowski G., Thomková K., Šporka F., Starek D.., Šurka J., Milovský R., Hamerlík L., Tracking human impact in a mining landscape using lake sediments. A multi-proxy palaeolimnological study, „Palaeogeography, Palaeoclimatology, Palaeoecology”, 504, 2018, s. 23-33.

Bogucka M., Samsonowicz H., Dzieje miast $i$ mieszczaństwa w Polsce przedrozbiorowej, Wrocław 1986.

Boroda K., Guzowski P., Przeliczniki demograficzne $w$ szacunkach zaludnienia terenów wiejskich w Królestwie Polskim w drugiej potowie XVI wieku, „Przeszłość Demograficzna Polski”, 37 (2), 2015, s. $53-75$.

Chodyła Z., Zarys dziejów osadnictwa olęderskiego w Polsce 1547-1864, w: Olędry. Przestrzenie wokót nas, Poznań 2006, s. 32-71.

Cui Q.Y., Gaillard M.J., Lemdahl G., Stenberg L., Sugit S., Zernova G., Historical land-use and landscape change in southern Sweden and implications for present and future biodiversity, „Ecology and Evolution”, 4 (18), 2014, s. 3555-3570.

Cywa K., Trees and shrubs used in medieval Poland for making everyday objects, „Vegetation History and Archaeobotany", 27 (1), 2018, s. 111-136.

Człowiek w średniowieczu. Między biologia a historia, red. A. Szymczakowa, Łódź 2009.

Dietze E., Theuerkauf M., Bloom K., Brauer A., Dörfler W., Feeser I., Feurdean A., Gedminienè L., Giesecke T., Jahns S., Karpińska-Kołaczek M., Kołaczek P., Lamentowicz M., Latałowa M., Marcisz K., Obremska M., Pędziszewska A., Poska A., Rehfeld K., Stančikaitė M., Stivrins N., Święta-Musznicka J., Szal M., Vassiljev J., Veski S., Wacnik A., Weisbrodt D., Wiethold J., Vannière B., Słowiński M., Holocene fire activity during low-natural flammability periods reveals scale-dependent cultural human-fire relationships in Europe, „Quaternary Science Reviews”, 201, 2018, s. 44-56.

Dynamics and conservation of the Pomeranian vegetation, ed. W. Fałtynowicz, M. Latałowa, J. Szmeja, Gdańsk-Poznań 1997.

Dzieduszycki W., Wykorzystanie surowca drzewnego we wczesnośredniowiecznej i średniowiecznej Kruszwicy, „Kwartalnik Historii Kultury Materialnej”, 24 (1), 1976, s. 35-54.

Dzieje Wielkopolski, t. 1: Do roku 1793, red. J. Topolski, Poznań 1969.

Encyclopedia of Quaternary science, ed. S.A. Elias, Amsterdam 2007.

Faliński J.B., Pioneer woody species and their role in the regeneration and secondary succession, w: Dynamics and conservation of the Pomeranian vegetation, ed. W. Fałtynowicz, M. Latałowa, J. Szmeja, GdańskPoznań 1997, s. 33-54.

Filbrandt A., Badania palinologiczne osadów limnicznych jeziora Kamionek, w: Wstep do paleoekologii
Lednickiego Parku Krajobrazowego, red. K. Tobolski, Poznań 1991, s. 81-86.

Frankiewicz B., Z dziejów ziemi pobiedziskiej, Pobiedziska 1990.

Fyfe R.M., Woodbridge J., Roberts C.N., Trajectories of change in Mediterranean Holocene vegetation through classification of pollen data, „Vegetation History and Archaeobotany", 27 (2), 2018, s. 351-364.

Gaillard M.J., Archaeological applications, w: History of Quaternary science, ed. S.E. Elias, Egham 2013, s. 880-903.

Gąsiorowski A., Najstarsze dokumenty poznańskiego domu joannitów, „Studia Źródłoznawcze”, 8, 1963, s. 83-95.

Gąsiorowski A., Najstarsze dokumenty poznańskiego domu joannitów. Dokończenie, „Studia Źródłoznawcze", 9, 1964, s. 47-60.

Gieysztorowa I., Wstep do demografii staropolskiej, Warszawa 1976.

Guzowski P., Poniat R., Przeliczniki demograficzne w szacunkach zaludnienia miast w Królestwie Polskim $w$ drugiej potowie XVI wieku, „Przeszłość Demograficzna Polski”, 37 (2), 2015, s. 77-93.

Haldon J., Mordechai L., Newfield T.P., Chase A.F., Izdebski A., Guzowski P., Labuhn I., Roberts N., History meets palaeoscience. Consilience and collaboration in studying past societal responses to environmental change, "Proceedings of the National Academy of Sciences of the United States of America”, 115 (13), 2018, s. 3210-3218.

Handbook of Holocene palaeoecology and palaeohydrology, ed. B.E. Berglund, Chichester-New York-Brisbane-Toronto-Singapore 1986.

History of Quaternary science, ed. S.E. Elias, Egham 2013.

Hładyłowicz K.J., Zmiany krajobrazu i rozwój osadnictwa w Wielkopolsce, Lwów 1932.

Hörnberg G., Josefsson T., DeLuca T.H., Higuera P.E., Liedgren L., Östlund L., Bergman I., Anthropogenic use of fire led to degraded Scots pine-lichen forest in northern Sweden, „Anthropocene”, 24, 2018, s. 14-29.

Izdebski A., Średniowieczni Rzymianie i przyroda, Interdyscyplinarna historia środowiskowa, Kraków 2018.

Izdebski A., Holmgren K., Weiberg E., Stocker S., Büntgen U., Florenzano A., Gogou A., Leroy S.A.G., Luterbacher J., Martrat B., Masi A., Mercuri A.M., Montanga P., Sadori L., Schneider A., Sicre M.A., Triantaphyllou M., Xoplaki E., Realising consilience. How better communication between archaeologists, historians and natural scientists can transform the study of past climate change in the Mediterranean, „Quaternary Science Reviews”, 136, 2016, s. $5-22$.

Izdebski A., Koloch G., Słoczyński T., Tycner M., Historia przyrodniczo-gospodarcza Polski w świetle 
analizy ilościowej danych palinologicznych, „Historyka. Studia Metodologiczne", 45, 2015, s. 127-160.

Izdebski A., Koloch G., Słoczyński T., Tycner M., On the use of palynological data in economic history. New methods and an application to agricultural output in Central Europe, 0-2000 AD, ,Explorations in Economic History", 59, 2016, s. 17-39.

Jankowska B., Szata roślinna okolic Gopta w późnym glacjale i holocenie oraz wptyw osadnictwa na jej rozwój w świetle badań paleobotanicznych, „Przegląd Archeologiczny", 27, 1980, s. 5-41.

Kara M., Najstarsze państwo Piastów - rezultat przetomu czy kontynuacji? Studium archeologiczne, Poznań 2009.

Kara M., Makohonienko M., Wielkopolska kraina grodow-krajobraz kulturowy kolebki państwa polskiego $w$ siwietle nowych ustalen chronologicznych, „Landform Analysis", 16, 2011, s. 20-25.

Kołaczek P., Gałka M., Lamentowicz M., Marcisz K., Kajukało-Drygalska K., Karpińska-Kołaczek M., Increased radiocarbon dating resolution of ombrotrophic peat profiles reveals periods of disturbance which were previously undetected, „Quaternary Geochronology”, 52, 2019, s. 21-28.

Kustra M., Pobiedziska wraz z okolica w średniowieczu i u progu nowożytności, Poznań-Pobiedziska-Gniezno 2013.

Late Glacial and Holocene history of vegetation in Poland based on isopollen maps, ed. M. Ralska-Jasiewiczowa, M. Latałowa, K. Wasylikowa, K. Tobolski, E. Madeyska, H.E. Wright Jr, C. Turner, W. Szafer, Kraków 2004.

Makohonienko M., Materiaty do postglacjalnej historii roślinności okolic Lednicy. Częśś II: Badania palinologiczne osadów Jeziora Lednickiego - rdzeń 1/86 i Wall/87, w: Wstęp do paleoekologii Lednickiego Parku Krajobrazowego, red. K. Tobolski, Poznań 1991, s. 63-70.

Makohonienko M., Przyrodnicza historia Gniezna, Poznań-Bydgoszcz 2000 (Prace Zakładu Biogeografii i Paleoekologii).

Makohonienko M., Makowiecki D., Rozwój krajobrazu kulturowego w otoczeniu jeziora Lednica na Wysoczyźnie Gnieźnieńskiej, „Landform Analysis”, 16, 2011, s. 32-38.

Marcisz K., Tinner W., Colombaroli D., Kołaczek P., Słowiński M., Fiałkiewicz-Kozieł B., Łokas E., Lamentowicz M., Long-term hydrological dynamics and fire history over the last 2000 years in $C E$ Europe reconstructed from a high-resolution peat archive, „Quaternary Science Reviews”, 112, 2015, s. $138-152$.

Mazzini I., Gliozzi E., Galaty M., Bejko L., Sadori L., Soulie-Marsche I., Kochi R., Van Welden A., Bushati S., Holocene evolution of Lake Shkodra. Multidisciplinary evidence for diachronic landscape change in northern Albania, "Quaternary Science Reviews", 136, 2016, s. 85-95.

Olędry. Przestrzenie wokót nas, Poznań 2006.

Olędrzy - osadnicy znad Wisty. Sasiedzi bliscy i obcy, red. A. Pabian, M. Targowski, Toruń 2016.

Poska A., Väli V., Tomson P., Vassilje J., Kihno K., Alliksaar T., Villoslada M., Saarse L., Sepp K., Reading past landscapes. Combining modern and historical records, maps, pollen-based vegetation reconstructions, and the socioeconomic background, „Landscape Ecology", 33 (4), 2018, s. 529-546.

Ralska-Jasiewiczowa M., Wacnik A., Mamakowa K., Nalepka D., Betula L. - Birch, w: Late Glacial and Holocene history of vegetation in Poland based on isopollen maps, ed. M. Ralska-Jasiewiczowa, M. Latałowa, K. Wasylikowa, K. Tobolski, E. Madeyska, H.E. Wright Jr, C. Turner, W. Szafer, Kraków 2004, s. $57-68$.

Riddell S., Erlendsson E., Gísladóttir G., Edwards K.J., Byock J., Zori D., Cereal cultivation as a correlate of high social status in medieval Iceland, „Vegetation History and Archaeobotany", 27 (5), 2018, s. 679-696.

Rusiński W., Osady tzw. Olędrów w dawnym województwie poznańskim, Poznań-Kraków 1947.

Rusiński W., Straty i zniszczenia w czasie wojny szwedzkiej (1655-60) orazjej skutki na obszarze Wielkopolski, w: Polska w okresie drugiej wojny pótnocnej, t. 2, red. K. Lepszy i in., Warszawa 1957, s. 261-306.

Sabatini F.M., Burrascano S., Keeton W.S., Levers C., Lindner M., Pötzschner F., Verkerk P.J., Bauhus J., Buchwald E., Chaskovsky O., Debaive N., Horváth F., Garbarino M., Grigoriadis N., Lombardi F., Duarte I.M., Meyer P., Midteng R., Mikac S., Mikolás S., Motta R., Mozgeris G., Nunes L., Panayotov M., Ódor P., Ruete A., Simovski B., Stillhard J., Svoboda M., Szwagrzyk J., Tikkanen O.-P., Volosyanchuk R., Vrska T., Zlatanov T., Kuemmerle T., Where are Europe's last primary forests?, „Diversity and Distributions", 24 (12), 2018, s. 1890-1892.

Sikora F., Dokumenty i kancelaria Przemysta I oraz Bolestawa Pobożnego 1239-1270 na tle wspótczesnej dyplomatyki wielkopolskiej, Wrocław 1969.

Stefański K., Wsie na "prawie niemieckim” $w$ Wielkopolsce w latach 1333-1370, „Roczniki Historyczne”, 37, 1971, s. 1-36.

Szady B., Dawna mapa jako źródto w badaniach geograficzno-historycznych w Polsce, „Kwartalnik Historii Kultury Materialnej”, 66 (2), 2018, s. 129-140.

Targowski M., Osadnictwo olęderskie w Polsce - jego rozwój i specyfika, w: Olędrzy - osadnicy znad Wisty. Sasiedzi bliscy i obcy, red. A. Pabian, M. Targowski, Toruń 2016, s. 11-26.

Theuerkauf M., Dräger N., Kienel U., Kuparinen A., Brauer A., Effects of changes in land management practices on pollen productivity of open vegetation 
during the last century derived from varved lake sediments, „The Holocene”, 25 (5), 2015, s. 733-744.

Tinner W., Hu F.S., Size parameters, size-class distribution and area-number relationship of microscopic charcoal. Relevance for fire reconstruction, „The Holocene", 13 (4), 2003, s. 499-505.

Tobolski K., Dotychczasowy stan badań paleobotanicznych i biostratygraficznych Lednickiego Parku Krajobrazowego, w: Wstęp do paleoekologii Lednickiego Parku Krajobrazowego, red. K. Tobolski, Poznań 1991, s. 11-34.

Topolski J., Przyczyny powstania i rozwój folwarku pańszczyźnianego, w: Dzieje Wielkopolski, t. 1: Do roku 1793, red. J. Topolski, Poznań 1969, s. $443-458$.

Tracking environmental change using lake sediments, ed. J.P. Smol, H.J.B. Birks, W.M. Last, Dordrecht 2001.

Trapote M.C., Rull V., Giralt S., Corella J.P., Montoya E., Vegas-Vilarrúbia T., High-resolution (subdecadal) pollen analysis of varved sediments from Lake Montcortès (southern Pyrenean flank). A fine-tuned record of landscape dynamics and human impact during the last 500 years, „Review of Palaeobotany and Palynology”, 259, 2018, s. 207-222.

Tyszkiewicz J., Cztowiek średniowiecza w przyrodzie: jako jej element $i$ moderator, w: Cztowiek w średniowieczu. Między biologia a historia, red. A. Szymczakowa, Łódź 2009, s. 15-24.

Tyszkiewicz J., Geografia historyczna. Zarys problematyki, Warszawa 2013.

Tyszkiewicz J., Ludzie i przyroda w Polsce średniowiecznej, Warszawa 1983.

Tyszkiewicz J., Środowisko naturalne i antroporegiony dorzecza Narwi przed 1000 lat, Wrocław 1975.
Veski S., Koppel K., Poska A., Integrated palaeoecological and historical data in the service of fine-resolution land use and ecological change assessment during the last 1000 years in Röuge, southern Estonia. Land use and ecological change assessment in southern Estonia, ,Journal of Biogeography”, 32 (8), 2005, s. $1473-1488$.

Wacnik A., Tylmann W., Bonk A., GoslarT., Enters D., Meyer-Jacob C., Grosjean M., Determining the responses of vegetation to natural processes and human impacts in north-eastern Poland during the last millennium. Combined pollen, geochemical and historical data, „Vegetation History and Archaeobotany", 25 (5), 2016, s. 479-498.

Whitlock C., Higuera P.E., McWethy D.B., Brilesi C.E., Paleoecological perspectives on fire ecology. Revisiting the fire-regime concept, „The Open Ecology Journal", 3, 2010, s. 6-23.

Whitlock C., Larsen C., Charcoal as a fire proxy, $\mathrm{w}$ : Tracking environmental change using lake sediments, ed. J.P. Smol, H.J.B. Birks, W.M. Last, Dordrecht 2001, s. 75-97.

Wielkopolska $w$ drugiej potowie XVI wieku, cz. 2: Komentarz, indeksy, red. K. Chłapowski, M. Słoń, Warszawa 2017 (Atlas historyczny Polski. Mapy szczegółowe XVI wieku, 4).

Wstęp do paleoekologii Lednickiego Parku Krajobrazowego, red. K. Tobolski, Poznań 1991.

Zdjęcie archeologiczne Polski, red. M. Konopka, Warszawa 1981.

Związek T., Drogi, w: Wielkopolska $w$ drugiej potowie XVI wieku, cz. 2: Komentarz, indeksy, red. K. Chłapowski, M. Słoń, Warszawa 2017 (Atlas historyczny Polski. Mapy szczegółowe XVI wieku, 4), s. 268-290.

\section{The Importance of Collaborative Historical and Palaeoecological Research on Human Impact on the Environment: The Case of the Kazanie Site in Eastern Greater Poland (Eastern Wielkopolska)}

\section{Summary}

The article presents an interdisciplinary approach to the research on the human impact on the environment in the past on the example of the Kazanie peat bog in Greater Poland (Wielkopolska) in the last 1200 years. Independent research was conducted using traditional archaeological sources (The Archaeological Survey of Poland) and historical sources related to economic history (charters, inventories of estates, tax registers) as well as paleoecological data (analyses of pollen and microscopic charcoal). The analyses of all types of sources provided consistent results indicating human economic activity as the main factor of changes in the local environment. It has also been confirmed that the integration of different approaches, from traditional historical analysis to high-resolution palaeoecological analyses, provide a broader view of the landscape transformations effected by human beings in the past. 
mgr Sambor Czerwiński - doktorant w Pracowni Ekologii i Monitoringu Mokradeł na Wydziale Nauk Geograficznych i Geologicznych UAM. Jego zainteresowania naukowe obejmują paleoekologię, w szczególności rekonstrukcję roślinności i wpływ człowieka w czasie holocenu (sambor.czerwinski@amu.edu.pl)

dr Piotr Guzowski - pracownik Centrum Badań Struktur Demograficznych i Gospodarczych Przednowoczesnej Europy Środkowo-Wschodniej Uniwersytetu w Białymstoku. Jego zainteresowania badawcze obejmują historię gospodarczą i demografię historyczną okresu preindustrialnego

(guzowski@uwb.edu.pl)

dr Monika Karpińska-Kołaczek - współpracuje z Pracownią Ekologii i Monitoringu Mokradeł na Wydziale Nauk Geograficznych i Geologicznych UAM. Jej zainteresowania badawcze obejmują zmiany zespołów palinomorf niepyłkowych i ameb skorupkowych w ciągu ostatnich 10 tys. lat (monika_kk@interia.eu)

prof. dr hab. Mariusz Lamentowicz - kierownik Pracowni Ekologii i Monitoringu Mokradeł na Wydziale Nauk Geograficznych i Geologicznych UAM. Jego zainteresowania badawcze obejmują paleoekologię i ekologię mokradeł, zmiany klimatu oraz ochronę przyrody

(mariuszl@amu.edu.pl)

dr hab. Mariusz Gałka - prof. Uniwersytetu Łódzkiego, zatrudniony w Katedrze Geobotaniki i Ekologii Roślin na Wydziale Biologii i Ochrony Środowiska. Jego zainteresowania badawcze obejmują rekonstrukcje paleoekologiczne, m.in. rozwoju roślinności obszarów mokradłowych (torfowisk, jezior, rzek) pod wpływem zmian klimatu, działalności człowieka i działalności wulkanicznej na terenie Europy, Azji, Ameryki Północnej, Ameryki Południowej oraz Afryki

(mariusz.galka@biol.uni.lodz.pl)

dr Piotr Kołaczek - pracownik Wydziału Nauk Geograficznych i Geologicznych UAM, specjalizujący się w analizie palinologicznej. Jego zainteresowania badawcze obejmują przemiany szaty roślinnej w kontekście zmian klimatycznych i działalności człowieka w ostatnich 120 tys. lat

(pkolacz@amu.edu.pl)

dr Adam Izdebski - adiunkt w Instytucie Historii Uniwersytetu Jagiellońskiego, kierownik „Palaeo-Science \& History" Independent Research Group Max Planck Institute for the Science of Human History w Jenie. Jego zainteresowania badawcze koncentrują się wokół historii środowiskowej Bizancjum

(bydgostiensis@gmail.com)

dr Radosław Poniat - pracownik Centrum Badań Struktur Demograficznych i Gospodarczych Przednowoczesnej Europy Środkowo-Wschodniej Uniwersytetu w Białymstoku. Jego zainteresowania badawcze obejmują historię społeczną okresu wczesnonowożytnego

(r.poniat@gmail.com)

Sambor Czerwiński - PhD student at the Laboratory of Wetland Ecology and Monitoring at the Faculty of Geographical and Geological Sciences, Adam Mickiewicz University in Poznań. His scholarly interests include palaeoecology, in particular vegetation reconstruction and human influence during the Holocene (sambor.czerwinski@amu.edu.pl)

Piotr Guzowski, PhD - employed at the Centre for the Study of Demographic and Economic Structures in Preindustrial Central and Eastern Europe, University of Białystok. His scholarly key interests include economic history and historical demography of preindustrial societies

(guzowski@uwb.edu.pl) 
Monika Karpińska-Kołaczek, PhD - she collaborates with the Laboratory of Wetland Ecology and Monitoring at the Faculty of Geographical and Geological Sciences, Adam Mickiewicz University in Poznań. Her research interests include changes in non-pollen palynomorphs and testate amoebae throughout last 10,000 years (monika_kk@interia.eu)

Mariusz Lamentowicz, Prof. Dr. hab. - head of the Laboratory of Wetland Ecology and Monitoring at the Faculty of Geographical and Geological Sciences, Adam Mickiewicz University in Poznań. His scholarly research interests cover palaeoecology and ecology of wetlands, climate changes and protection of nature (mariuszl@amu.edu.pl)

Mariusz Gałka, Dr. hab. - associate professor of the University of Łódź, employed at the Department of Geobotany and Plant Ecology, Faculty of Biology and Environmental Protection, University of Łódź. His research interests focus on palaeoecologic reconstructions, i.a. vegetation succession in wetlands (bogs, lakes, rivers) vs climate change, human activity, and volcanic activity in Europe, Asia, North America, South America, and Africa

(mariusz.galka@biol.uni.lodz.pl)

Piotr Kołaczek, PhD - member of the Faculty of Geographical and Geological Sciences, Adam Mickiewicz University in Poznań, specialising in palynological analysis. His scholarly interests include changes in plant vegetation in the context of climate change and human activity throughout last 120,000 years (pkolacz@amu.edu.pl)

Adam Izdebski, PhD - assistant professor at the Institute of History, Jagiellonian University in Kraków, head of the "Paleo-Science \& History" Independent Research Group Max Planck Institute for the Science of Human History in Jena. His research interests focus environmental history of Byzantium (bydgostiensis@gmail.com)

Radosław Poniat, PhD - employed at the Centre for the Study of Demographic and Economic Structures in Preindustrial Central and Eastern Europe, University of Białystok. His scholarly key interests include social history of the early modern period (r.poniat@gmail.com) 